\title{
1 Alternate response of Bacillus anthracis atxA and acpA to serum,
}

$2 \mathrm{HCO}_{3}-$ and $\mathrm{CO}_{2}$

$3 \psi^{\psi}$ Itai Glinert, "Elad Bar-David, Amir Ben-Shmuel, Assa, Sittner, Reut Puni, Shira Laredo, David Kobiler,

4 Shay Weiss and Haim Levy*

5

6 Department of Infectious Diseases, Israel Institute for Biological Research, P.O. Box 19, Ness Ziona 74100, Israel.

$7 \quad \psi$ equal contribution

8

9

10

11

12

13

14

15

16

17

18

19

20

21

22

23

$24 *$ corresponding author

25 haiml@iibr.gov.il 


\section{Abstract}

27 Bacillus anthracis overcome host immune response by producing capsule and secreting toxins. Production

28 of these virulence factors in response to host environment was shown to be regulated by atx $A$, the major 29 virulence regulator, that was shown to be activated by $\mathrm{HCO}_{3}{ }^{-}$and $\mathrm{CO}_{2}$. While toxin production is regulated 30 directly by at $A$, capsule production is mediated by either one of two regulators; acp $A$ and acp $B$. In 31 addition, it was demonstrated that acpA gene have at least two promotors were one of them was linked 32 to atXA. We used a genetic approach to study capsule and toxin production under different conditions. 33 Unlike previous works that used $\mathrm{NBY}-\mathrm{HCO}_{3}^{-}$medium in a $\mathrm{CO}_{2}$ enriched atmosphere, we used a SDMEM 34 based medium in which toxins and capsule production can be induced in $\mathrm{B}$. anthracis in ambient or $\mathrm{CO}_{2}$ enriched atmosphere. Using this system, we could differentiate between induction by $10 \% \mathrm{NRS}, 10 \% \mathrm{CO}_{2}$

36 or $0.75 \% \mathrm{HCO}_{3}$. In response to high $\mathrm{CO}_{2}$, capsule production is induced by acp $A$ in an atxA independent manner, while little or no toxins (protective antigen PA) is produced. at $X A$ is activated in response to serum in $\mathrm{CO}_{2}$ independent manner and induce toxins production and capsule production in an acpA or acp $B$ dependent manner. $\mathrm{HCO}_{3}$ activates atxA as well, however in non-physiological concentrations. Our

40 findings might be relevant to the first stages of inhalational infection were in the dendritic cell the 41 germinating spore must be protected by the capsule without effecting cell migration to the draining lymph-node by toxin secretion. 
bioRxiv preprint doi: https://doi.org/10.1101/2022.02.21.481328; this version posted February 21, 2022. The copyright holder for this preprint (which was not certified by peer review) is the author/funder, who has granted bioRxiv a license to display the preprint in perpetuity. It is made available under aCC-BY 4.0 International license.

\section{Introduction}

Bacillus anthracis, the causative agent of anthrax, is a gram positive, spore forming bacterium that infect humans via three major routes; lung (inhalation), cutaneous and the gut (digestion) [1,2]. The infectious form of $B$. anthracis is the spore, that are durable and survive in the environment for decades. In response to the host environment the spore germinates and overcomes the immune system by two major virulence factors; poly- $\delta$-D-glutamic antiphagocytic capsule and the tripartite toxins [3]. The capsule producing genes are encoded as a polycistronic gene cluster on the $\mathrm{pXO2}$ virulence plasmid, $\operatorname{cap} B, C, A, D, E$. CapB and CapC are the polymerization units while CapA and CapE form the transport channel that exports the capsule polymer from the cytoplasm through the cell wall and membrane to the cell surface [4-6]. On the cell surface CapD hydrolyzes the polymer to shorter chains and covalently link them to the cell wall [7]. The same CapD regulate the length of the bound polymer chains by its hydrolyzation activity $[4,8,9]$. The tripartite toxins are encoded by the pXO1 virulence plasmid, by pag (protective antigen-PA), lef (lethal factor-LF) and cya (edema factor-EF) [1]. LF is a metalloprotease that specifically cleaves members of the MAP kinase regulatory pathway of mammalian cells [10]. EF is a potent calmudolin dependent adenylate cyclase that interferes with cell regulation by elevating the internal cAMP levels [11]. Both LF and EF are driven into the mammalian cells by PA that binds specific receptors ANTXR1 (TEM8) and ANTXR2 (CMG2) [12]. PA binds to the receptor, processed by cell associated furin and oligomerize to form a heptamer that bind LF and EF in a 2:1 ratio $[12,13]$. The complex is then phagocyted and upon lysosome fusion and $\mathrm{pH}$ drop the PA complex undergoes a conformational modification the results in LF and EF injection into the cytoplasm. Toxin activity cases, among other, inactivation of immune cells and immune response [12].

The at $X A$ was shown to be the major virulence regular of $B$. anthracis virulent $[2,14]$. This $p X O 1$ encoded protein activates a cascade of regulatory processes that results in up and down regulation of chromosomal and plasmid encoded genes [15]. The capsule production is regulated by two pXO2 encoded gene products, acpA [15] and $a c p B[16,17]$. Though it was demonstrated that at $x A$ regulates these two genes [18], it is not essential for capsule production since $\Delta p X 01$ strains produces capsule $[19,20]$. Since $B$. anthracis do not produce toxins and capsule under normal laboratory growth conditions, a specific host simulating growth condition were generated. It was reported that growth of B. anthracis in NBY broth supplemented with glucose and bicarbonate in $5-15 \% \mathrm{CO}_{2}$ atmosphere results in toxin secretion and capsule production $[16,20-22]$. These growth conditions were used to study different aspects of virulence regulation in $B$. anthracis and these findings indicated that at $x A$ in induced in response to $\mathrm{HCO}_{3}$ and $\mathrm{CO}_{2}$, activating both toxin and capsule production. This concept implies that toxins and capsule are produced simultaneously in the host. 
78 Previously we reported that growth of B. anthracis in SDMEM high glucose cell culture medium

79 supplemented with pyruvate glutamine, nonessential amino acid (referred to in this work as SDMEM) with

80 addition of $10 \%$ serum and incubated in $10 \% \mathrm{CO}_{2}$ atmosphere, induces virulence factor production $[17,19]$.

81 Herein we demonstrate that SDMEM can be used to examine the effect of serum (normal rabbit serum -

$82 \mathrm{NRS}), \mathrm{HCO}_{3}-$ and/or $\mathrm{CO}_{2}$ atmosphere, on the regulation of toxin or capsule production. Using a genetic

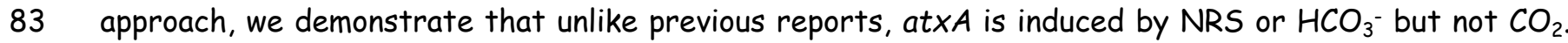

84 The capsule regulator acpA was induced by $\mathrm{CO}_{2}$ in an atxA independent manner and by NRS in an atxA

85 dependent manner. The acp $B$ was activated only in at $x A$ dependent manner when deletion of the later

86 resulted in loss of acpB regulation of capsule production. Our results indicate that the capsule could be

87 produced independently of the toxins while the toxins will always be co-induced with the capsule. 
Materials and Methods

90 Bacterial strains, media and growth conditions.

91 Bacterial strains used in this study are listed in Table 1. For the induction of toxins and capsule production, a modified DMEM (supplemented with $4 \mathrm{mM}$ L-glutamine, $1 \mathrm{mM}$ Sodium pyruvate, $1 \%$ nonessential amino acid) that was supplemented with $10 \%$ normal rabbit serum or $0.75 \% \mathrm{NaHCO}$ (Biological Industries - Israel). Spores of the different mutants were seeds to a concentration of $5 \times 105 \mathrm{CFU} / \mathrm{ml}$ and grown in 96 well tissue culture plate $(100 \mu \mathrm{l}$ per wail) for 5 or $24 \mathrm{~h}$ at 37 o C in ambient or $10 \% \mathrm{CO} 2$ atmosphere.

Mutant strain construction.

Oligonucleotide primers used in this study were previously described $[17,19,23]$. The oligonucleotide primers were designed according to the genomic sequence of B. anthracis Ames strain. Genomic DNA (containing the chromosomal DNA and the native plasmids, pX01 and pX02) for cloning the target gene fragments was extracted from the Vollum strain as previously described [24]. Target genes were disrupted by homologous recombination, using a previously described method [25]. In general, gene deletion or insertion was accomplished by a marker-less allelic exchange technique that replaced the complete coding region with the SpeI restriction site or the desired sequence. At the end of the procedure the resulting mutants did not code for any foreign sequences and the only modification is the desired gene insertion or deletion. Deletion of the at $X A$ gene was performed as previously described [25]. All the mutants were tested for their ability to produce capsule by incubation in modified DMEM. The capsule was visualized by negative staining with India ink.

Toxin quantification

Protective antigen (PA) concentration was determine by capture ELISA using the combination of a 
Strain

\section{B. anthracis}

Vollum

Vollum $\triangle \mathrm{p} X 01$

Vollum $\triangle a t \times A$

Vollum $\triangle a c p A$

Vollum $\triangle a c p B$

Vollum $\triangle a c p A \triangle a c p B$

Vollum $\Delta$ pag $\triangle c y a \Delta$ lef

Vollum $\Delta p a g \Delta c y a \Delta l e f \Delta a c p A$

Vollum $\Delta p a g \Delta c y a \Delta l e f \Delta a c p B$

Vollum $\Delta p a g \Delta c y a \Delta l e f \Delta a c p A \Delta$

$a c p B$

Vollum $\triangle p a g \Delta c y a \Delta l e f \triangle a c p A \Delta$ at $\times A$

Vollum $\triangle p a g \Delta c y a \Delta l e f \triangle a c p B \Delta$ atxA

Vollum $\triangle \mathrm{p} X 02 \triangle b c \mid A:$ :

pag prom $_{\text {p }: c a p A-E}$

Vollum $\triangle \mathrm{p} X 02 \triangle b c \mid A::$

pag $_{\text {prom }}:: c a p A-E \Delta a t \times A$
ATCC 14578

Complete deletion of the plasmid pXO1

Complete deletion of the at $X A$ gene

Complete deletion of the acpA gene

Complete deletion of the acp $B$ gene

Complete deletion of the acp $A$ and $a c p B$ genes

Complete deletion of the pag, lef and cya genes

Complete deletion of the acpA gene in the

Vollum $\triangle$ pag $\triangle c y a \Delta$ lef mutant

Complete deletion of the acp $B$ gene in the

Vollum $\Delta$ pag $\Delta c y a \Delta$ lef mutant

Complete deletion of the acpA and $а с p B$ genes in the

Vollum $\triangle$ pag $\triangle c y a \Delta$ lef mutant

Complete deletion of the at $X A$ gene in the

Vollum $\triangle$ pag $\triangle c y a \triangle$ lef $\triangle a c p A$ mutant

Complete deletion of the at $X A$ gene in the

Vollum $\triangle p a g \Delta c y a \Delta l e f \triangle a c p B$ mutant

Genome insertion of the pagA promotor in front of the

CAP operon replacing the bclA gene in the Vollum $\triangle \mathrm{pXO2}$

Deletion of the at $X A$ gene from the strain having

genome insertion of the pagA promotor in front of the

IIBR collection

IIBR collection

This study

This study

This study

CAP operon replacing the bclA gene in the Vollum $\triangle \mathrm{pXO2}$ 
129 The effect of supplements and growth condition on capsule production in SDMEM medium. The basic 130 medium that we used to test capsule and toxins induction in response to different supplements and growth condition was high glucose DMEM that was supplanted with glutamine, pyruvate and non-essential amino acid and is referred to as SDMEM. Since we chose to grow the bacteria in 96 well tissue culture microplate we tested the effect of volume on capsule production. We have inoculated B. anthracis Vollum spores

$134\left(5 \times 10^{5} \mathrm{CFU} / \mathrm{ml}\right)$ in $100 \mu \mathrm{l}, 200 \mu \mathrm{l}$ and $300 \mu \mathrm{l}$ SDMEM at $37^{\circ} \mathrm{C}$ in ambient atmosphere for $24 \mathrm{~h}$. No capsule 135 production could be detected in $100 \mu$ I SDMEM (Figure 1) but increasing the culture volume to $300 \mu l$ results in capsule production were in $200 \mu$ l only part of the bacteria were encapsulated (Figure 1). This effect could result from dissolved $\mathrm{CO}_{2}$ generated by bacterial growth and limited gas exchange in the 138 case of low surface to liquid volume. This is supported by the finding that growth in $10 \% \mathrm{CO}_{2}$ atmosphere 139 induces capsule accumulation even in medium volume of $100 \mu l$ SDMEM (Figure 1). Normal rabbit serum 140 (NRS) induces capsule accumulation regardless of atmosphere composition, since all the bacteria were 141 encapsulated in ambient or $10 \% \mathrm{CO}_{2}$ atmosphere (Fig 1). Based on these experiments we used 100 $\mu$ l SDMEM medium in 96 well tissue-culture plates for all of our induction experiments. 

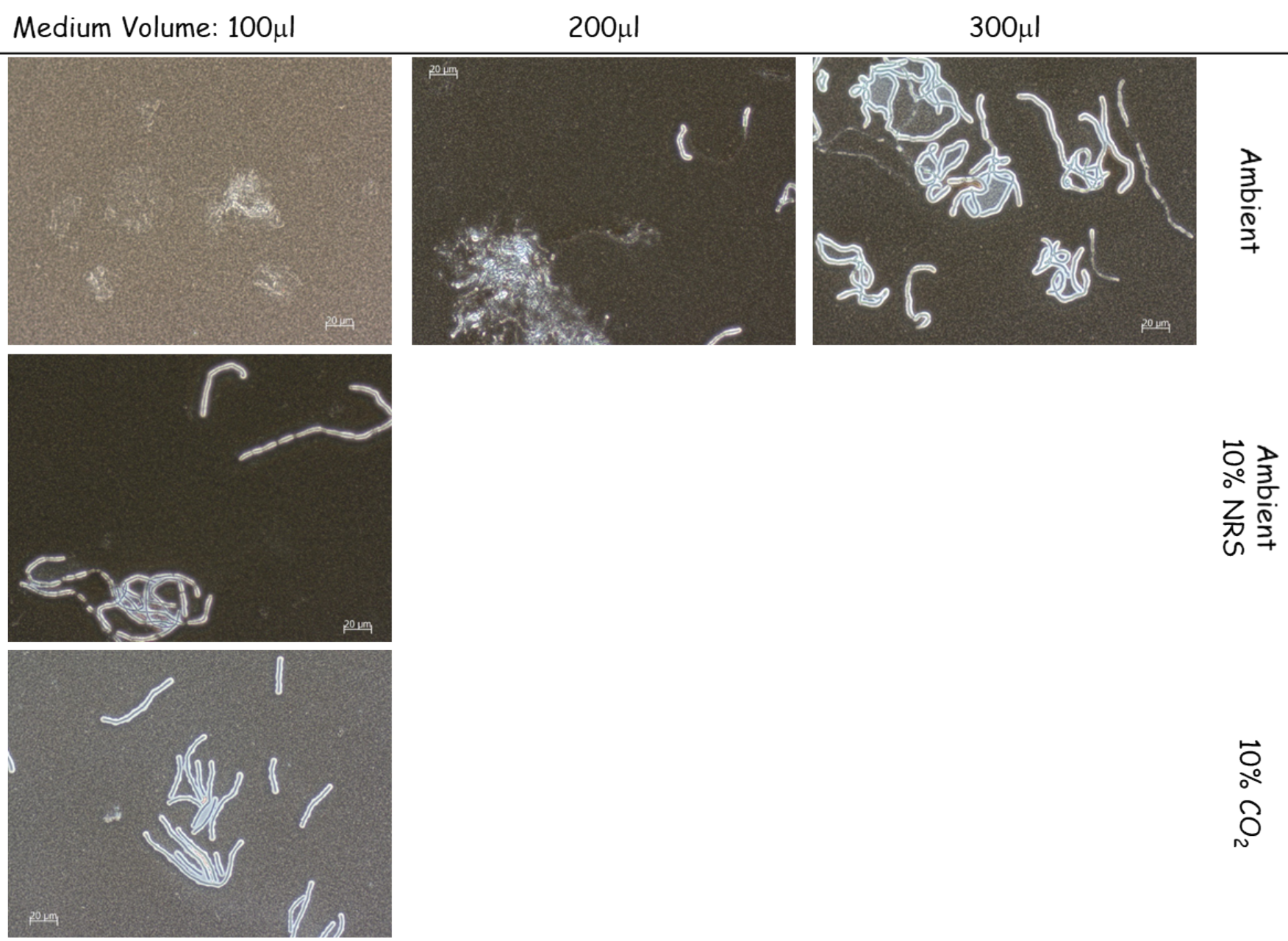

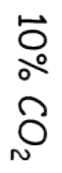
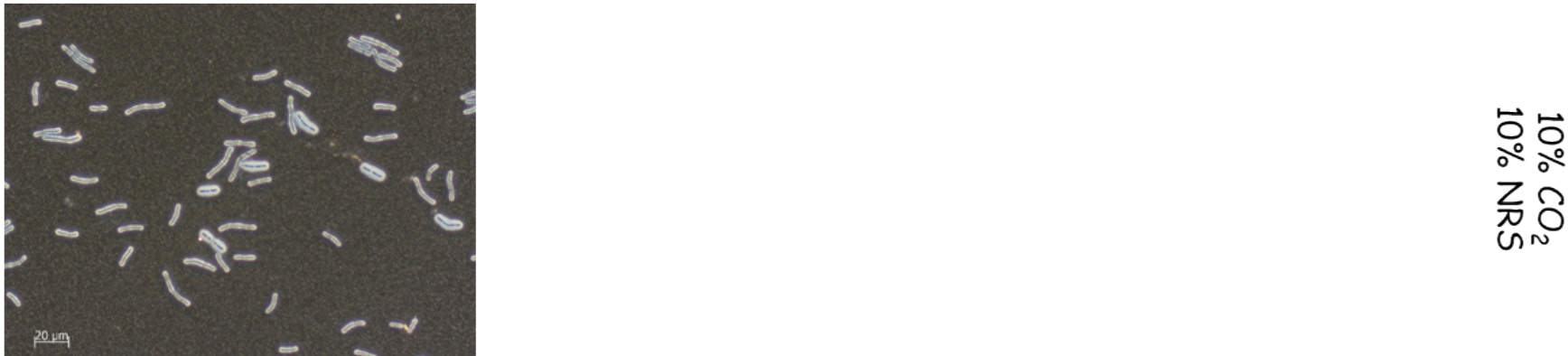

144 Figure 1. The effect of growth conditions on capsule accumulation by B. anthracis Vollum. Spores 145 were seeded into $100 \mu \mathrm{l}, 200 \mu \mathrm{l}$ or $300 \mu \mathrm{l}$ of DMEM and incubated at $37^{\circ} \mathrm{C}$ in an ambient atmosphere (upper panel) for $14624 \mathrm{~h}$. To examine the effect of serum or $\mathrm{CO}_{2}$ on capsule production, spores were seeded into $100 \mu \mathrm{I} D M E M$ as is or 147 supplemented with $10 \%$ NRS and incubated at $37{ }^{\circ} \mathrm{C}$ in an ambient or $10 \% \mathrm{CO}_{2}$ atmosphere (as indicated on the right) 148 for $24 \mathrm{~h}$. The presence or absence of capsule were determined by India ink negative staining (capsule seen as a bright outer layer).

150 The role of atxA on capsule production and toxin secretion under different growth conditions. To 151 test the role of atXA on capsule and toxins production following growth in SDMEM under the different growth conditions we compared the wild type Vollum strain to the $\triangle \mathrm{pXO1}$ or $\triangle a t X A$ mutants. None of the 
bioRxiv preprint doi: https://doi.org/10.1101/2022.02.21.481328; this version posted February 21, 2022. The copyright holder for this preprint (which was not certified by peer review) is the author/funder, who has granted bioRxiv a license to display the preprint in perpetuity. It is made available under aCC-BY 4.0 International license.

153

154

strains produced capsule under ambient atmosphere in the un-supplemented SDMEM medium (Figure 2).

Addition of $10 \%$ NRS resulted in capsule production by the wild type Vollum strain but not by the atx $A$ null mutants ( $\triangle \mathrm{p} X O 1$ or $\triangle a t \times A$ Figure 2). In a $10 \% \mathrm{CO}_{2}$ atmosphere all the strains were encapsulated regardless of the presence or absence of atxA. Hence, the effect of NRS in the presence of $\mathrm{CO}_{2}$ on capsule production under these conditions could not be resolved since capsule production is induced in response to the presence of $\mathrm{CO}_{2}$ or NRS. Since it appeared that the response to NRS is atxA dependent we can assume that capsule production in the atx $A$ null mutants derived form only the $\mathrm{CO}_{2}$ (Figure 2 ).

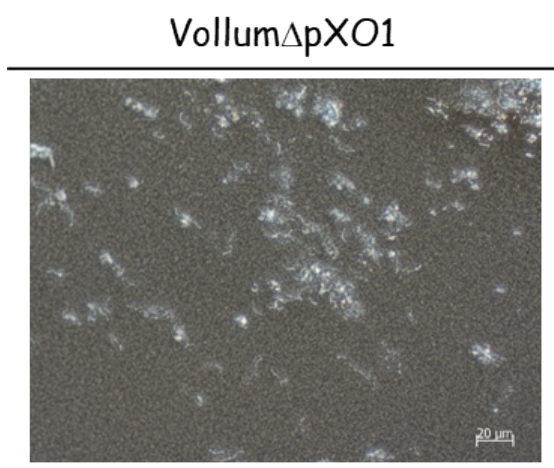

Vollum $\triangle a t \times A$

Vollum
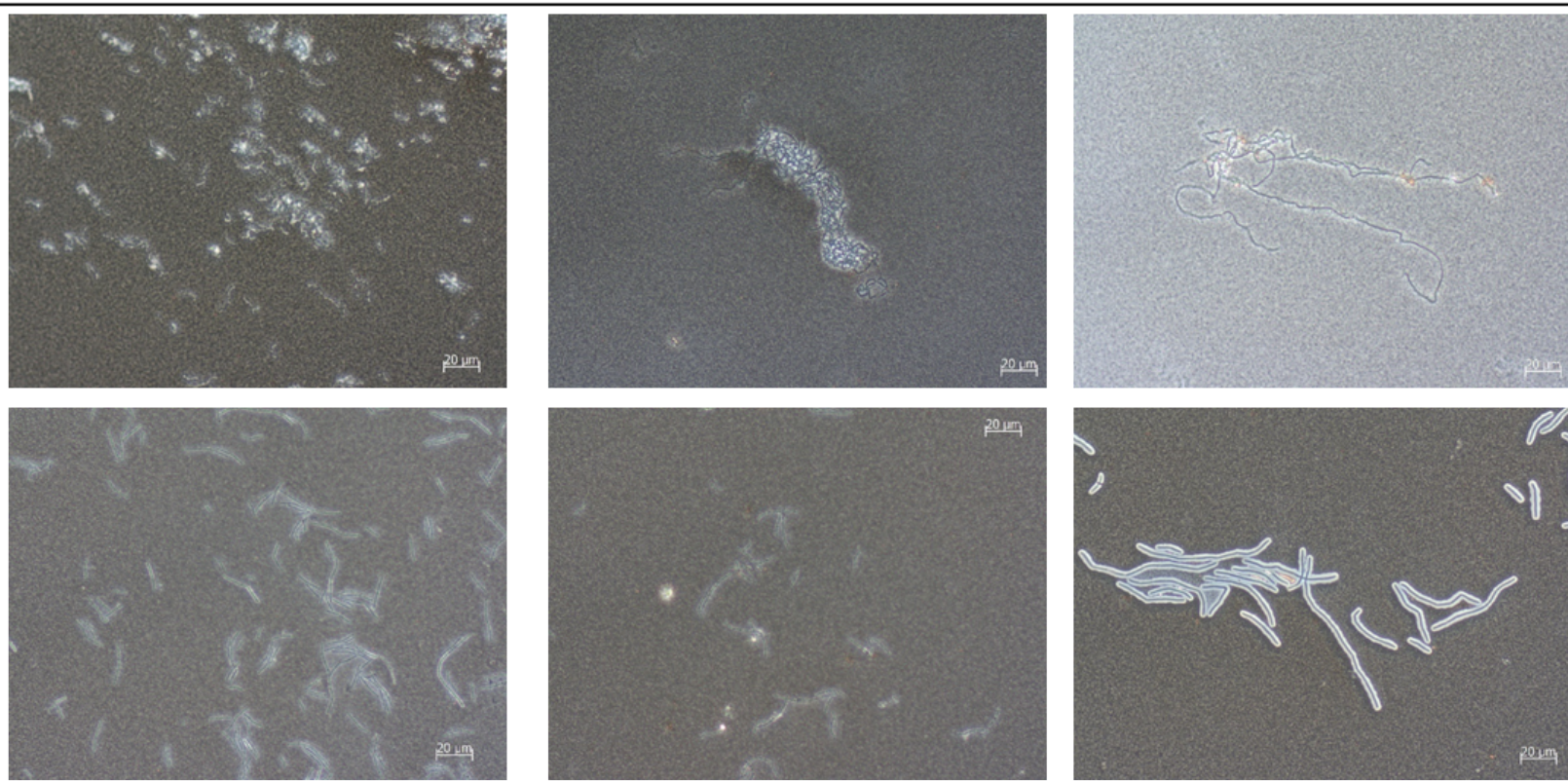

$\frac{7}{3}$
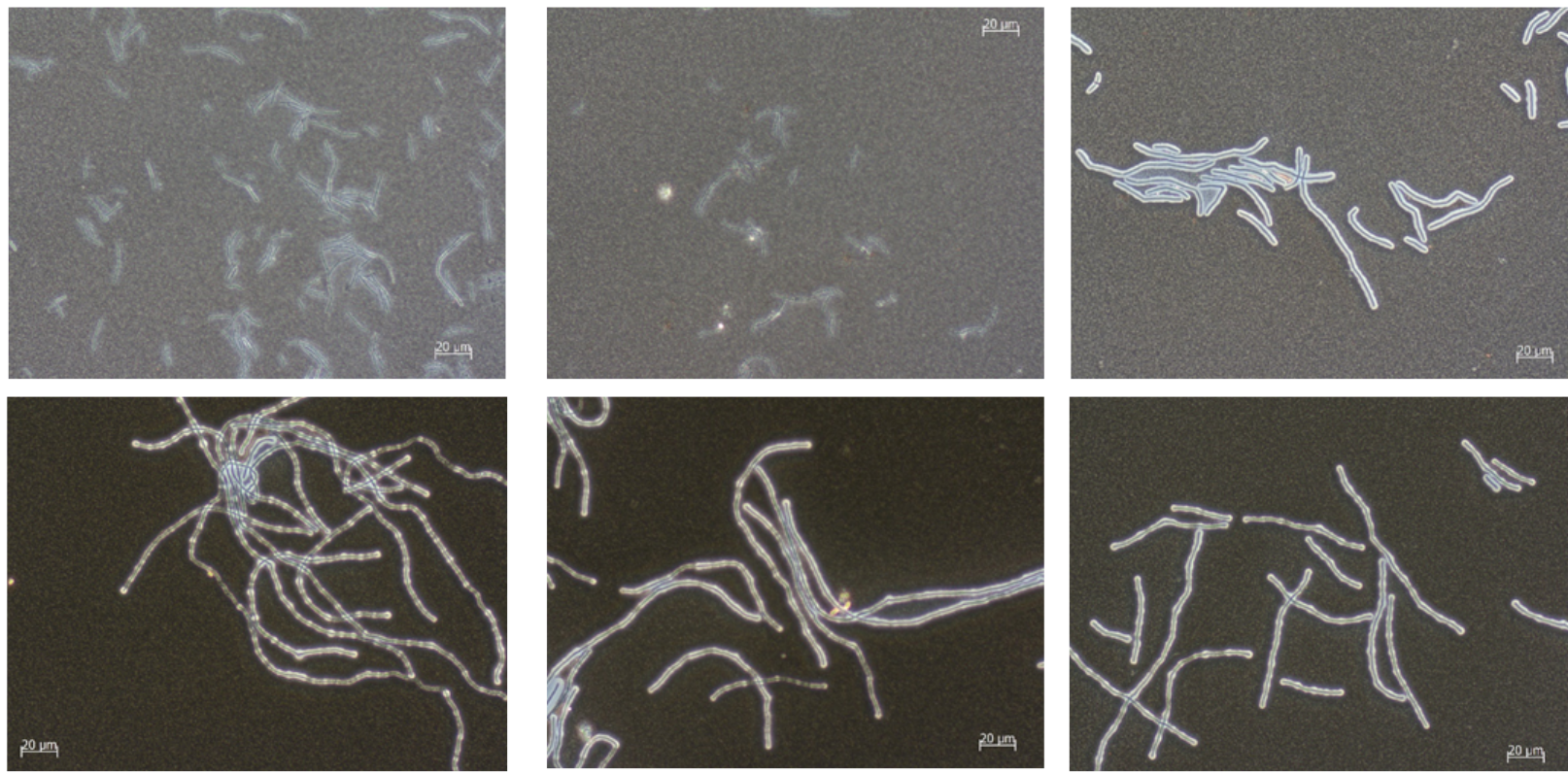

它京
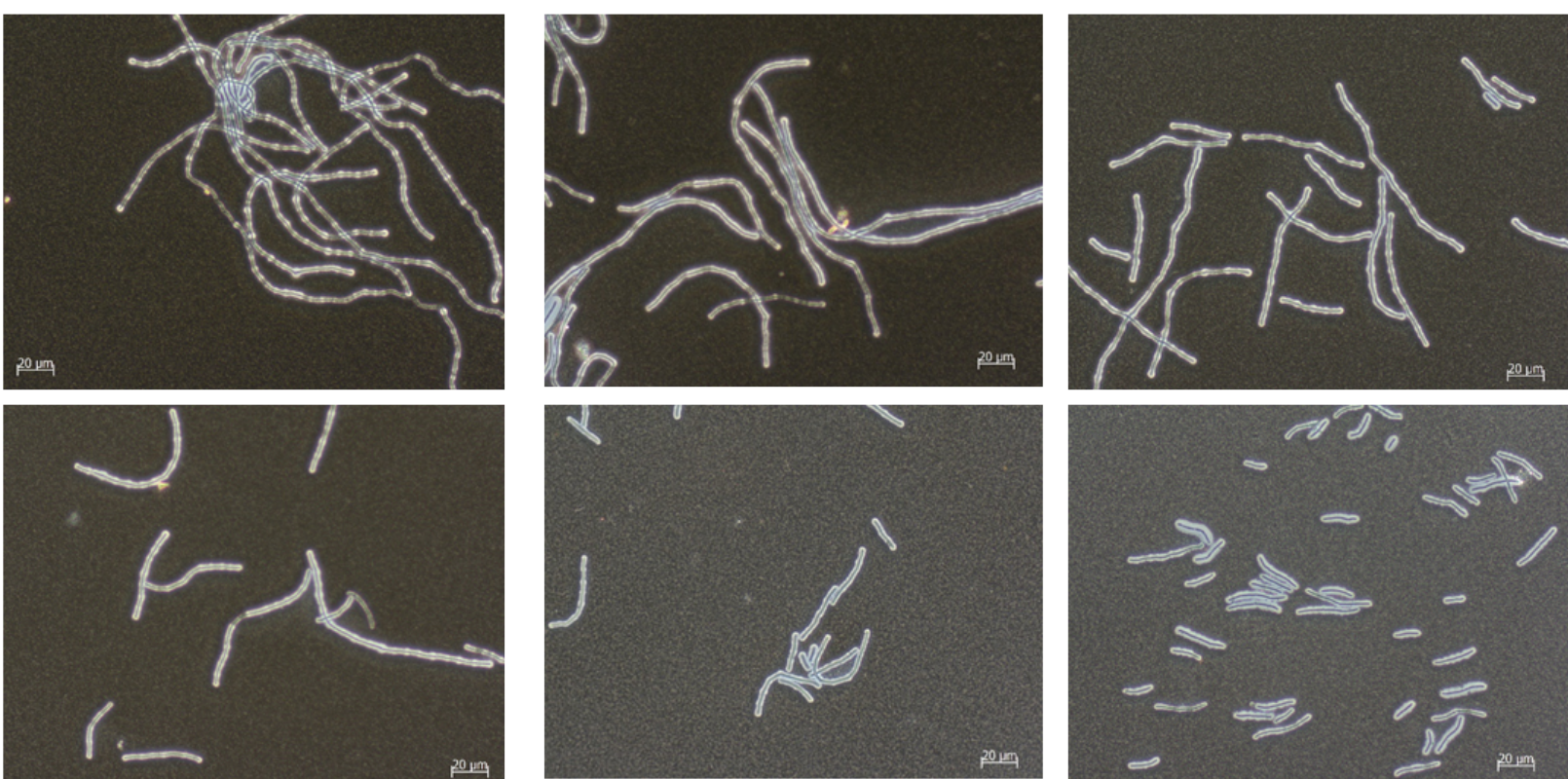

ㅇํㅇ
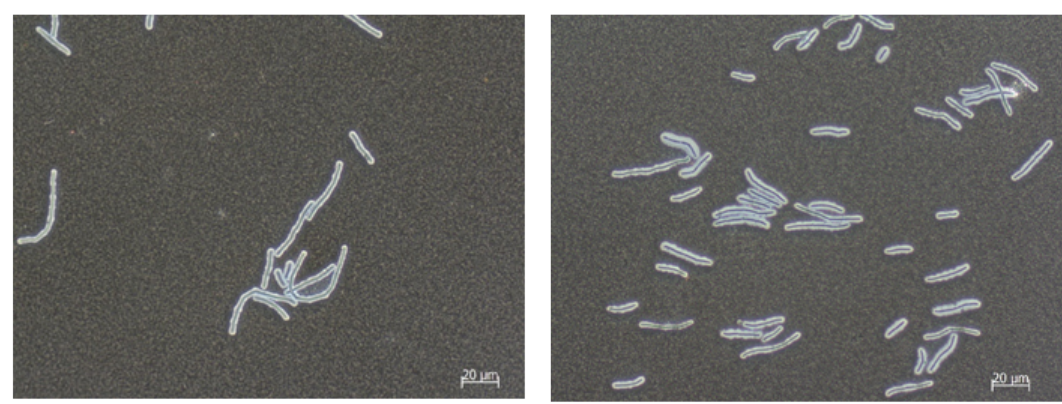

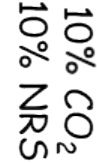

161 Figure 2. Capsule production of the Vollum wild type, $\triangle \mathrm{pXO1}$ or $\triangle x t X A$ mutants under different growth conditions. The effect of the absence of $\mathrm{pXO1}$ or the atXA gene on capsule accumulation under the different growth 
conditions, Spores of the wild type and different mutants (top panel) were seeded into $100 \mu$ l of DMEM as is or supplemented with $10 \% \mathrm{NRS}$ and incubated at $37{ }^{\circ} \mathrm{C}$ in an ambient or $10 \% \mathrm{CO}_{2}$ atmosphere (as indicated on the right) for $24 \mathrm{~h}$. The presence or absence of capsule were determined by India ink negative staining (capsule seen as a bright outer layer).

As at $x A$, the major virulence regulator is regulating the toxins expression (LF, EF and PA), we determined the concentration in the growth medium of the Vollum and Vollum $\triangle a t \times A$ mutant (in $\triangle p X O 1$ al the tox genes are missing). Toxins secretion was determined by ELISA of the most abundant component, the PA. PA was detected only when the growth medium was supplemented with NRS (Table 1). According to our results (Table 1), $\mathrm{CO}_{2}$ enriched atmosphere reduced the PA levels to about $30 \%$, reduction that was maintained through different independent experiments. However, we cannot eliminate the possibility that this difference results from differences in growth rates under these conditions. No PA secretion could be detected in the at $x$ A null mutant under any of the tested growth conditions.

The fact that we find that $\mathrm{CO}_{2}$ atmosphere by itself do not activate atxA dependent toxin induction, is surprising since it was repeatedly demonstrated that at $X \mathrm{~A}$ is regulated by $\mathrm{HCO}_{3}$. Therefore, we tested capsule production and toxin secretion in a SDMEM supplemented with $0.75 \% \mathrm{HCO}_{3}^{-}$in $10 \% \mathrm{CO}_{2}$ atmosphere. The $\mathrm{CO}_{2}$ atmosphere was chosen since the addition of $\mathrm{HCO}_{2}$ - dramatically increase the levels of the soluble $\mathrm{CO}_{2}$ in the medium even under ambient conditions and we were interested to maintain the controls in as close conditions as possible.

Table 1. Protective Antigen secretion of Vollum or Vollum $\triangle a t x A$ under different growth conditions.

\begin{tabular}{|c|c|c|c|c|}
\hline & Vollum $\Delta a t \times A$ & Vollum & Atmosphere & Supplements \\
\hline \multirow{4}{*}{$\begin{array}{l}\bar{\xi} \\
\text { g) } \\
\frac{\pi}{\alpha}\end{array}$} & $<0.1$ & $<0.1$ & Ambient & \\
\hline & $<0.1$ & 8.7 & Ambient & $10 \%$ NRS \\
\hline & $<0.1$ & $<0.1$ & $10 \% \mathrm{CO}_{2}$ & \\
\hline & $<0.1$ & 2.6 & $10 \% \mathrm{CO}_{2}$ & $10 \%$ NRS \\
\hline
\end{tabular}




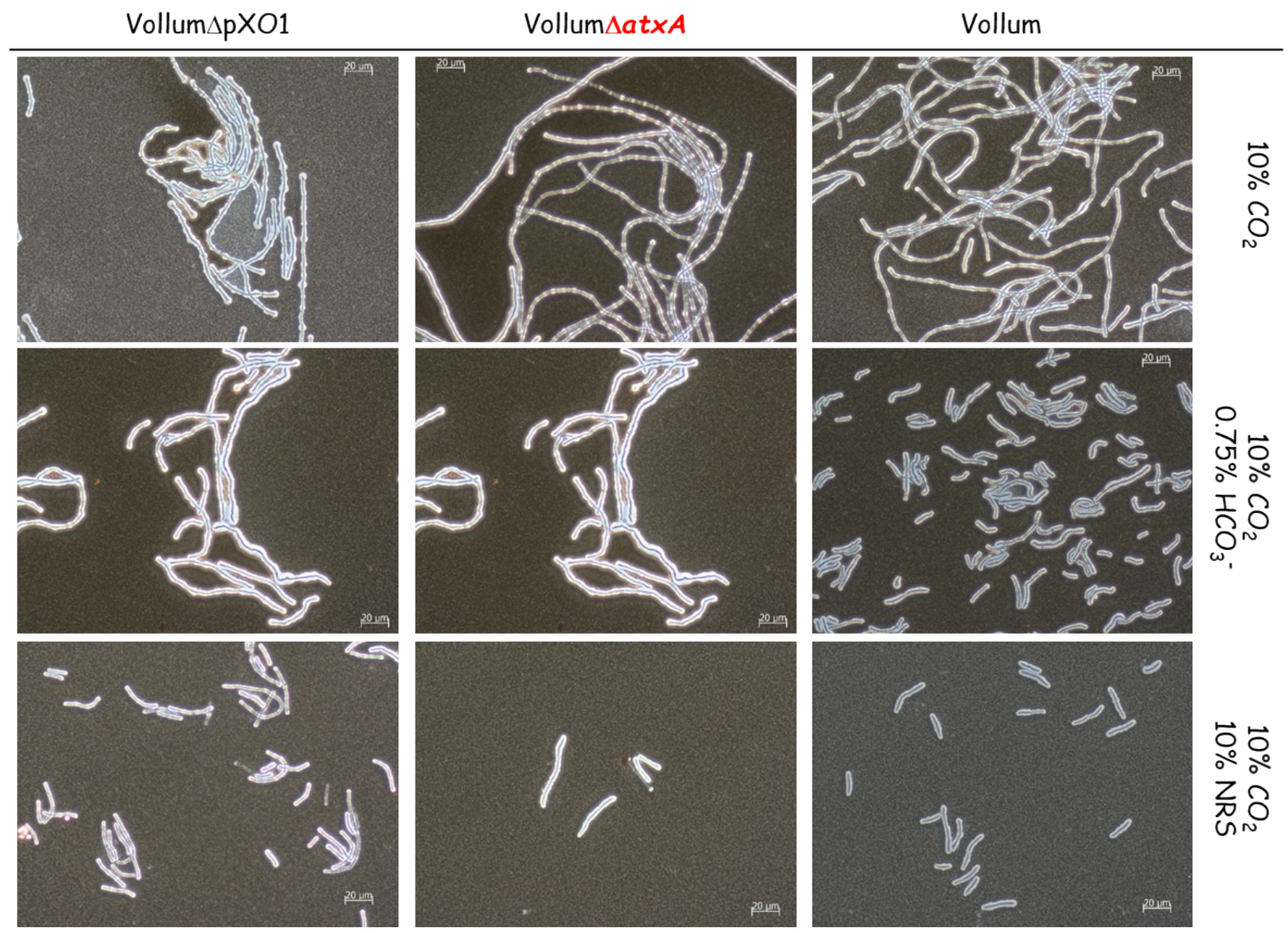

Figure 3. Effect of $0.75 \% \mathrm{HCO}_{3}^{-}$on capsule accumulation of Vollum, Vollum $\triangle$ at $X A$ or Vollum $\triangle \mathrm{pXO1}$. Spores

were seeded into $100 \mu \mathrm{l}$ of DMEM as is or supplemented with $0.75 \% \mathrm{HCO}_{3}^{-}$or $10 \% \mathrm{NRS}$ and incubated at $37^{\circ} \mathrm{C}$ in an atmosphere of $10 \% \mathrm{CO}_{2}$ for $24 \mathrm{~h}$. The presence or absence of capsule were determined by India ink negative staining (capsule seen as a bright outer layer). The different mutations are indicated (top panel).

Table 2. PA secretion by Vollum and Vollum $\triangle$ atx $x$ in medium supplemented with $\mathrm{HCO}_{3}{ }^{-}$

\begin{tabular}{|c|c|c|c|c|}
\hline & Vollum $\Delta a t \times A$ & Vollum & Atmosphere & Supplements \\
\hline \multirow{3}{*}{$\begin{array}{l}\bar{\xi} \\
\text { g } \\
\frac{\Sigma}{a}\end{array}$} & $<0.1$ & $<0.1$ & $10 \% \mathrm{CO}_{2}$ & \\
\hline & $<0.1$ & 3.12 & $10 \% \mathrm{CO}_{2}$ & $0.75 \% \mathrm{HCO}_{3}-$ \\
\hline & $<0.1$ & 5.3 & $10 \% \mathrm{CO}_{2}$ & $10 \%$ NRS \\
\hline
\end{tabular}

As we demonstrated capsule accumulation is $\mathrm{CO}_{2}$ dependent, therefore all the strains are encapsulated under all the condition tested (Figure 3). PA secretion was tested only in the growth medium of Vollum and Vollum $\triangle a t \times A$. Supplementing the SDMEM with $0.75 \% \mathrm{HCO}_{3}$ - induced PA secretion by the Vollum strain but not by the Vollum $\triangle$ at $X A$ mutant, indicating that $\mathrm{HCO}_{3}$ - induce toxin secretion in an at $X A$ dependent manner (Table 2). To validate these findings, we used a previously reported Vollum $\triangle \mathrm{pXO2}$ chimera in 
bioRxiv preprint doi: https://doi.org/10.1101/2022.02.21.481328; this version posted February 21, 2022. The copyright holder for this preprint (which was not certified by peer review) is the author/funder, who has granted bioRxiv a license to display the preprint in perpetuity. It is made available under aCC-BY 4.0 International license.

which we substituted the genomic bclA gene with a $P A_{\text {prom }}$ regulated $C A P$ operon. In this case capsule accumulation is an indication for at $X A$ dependent activation of the PA promotor that activates the CAP genes.

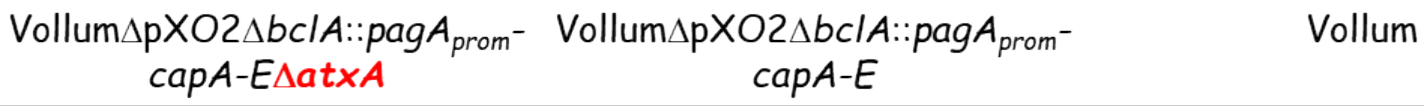
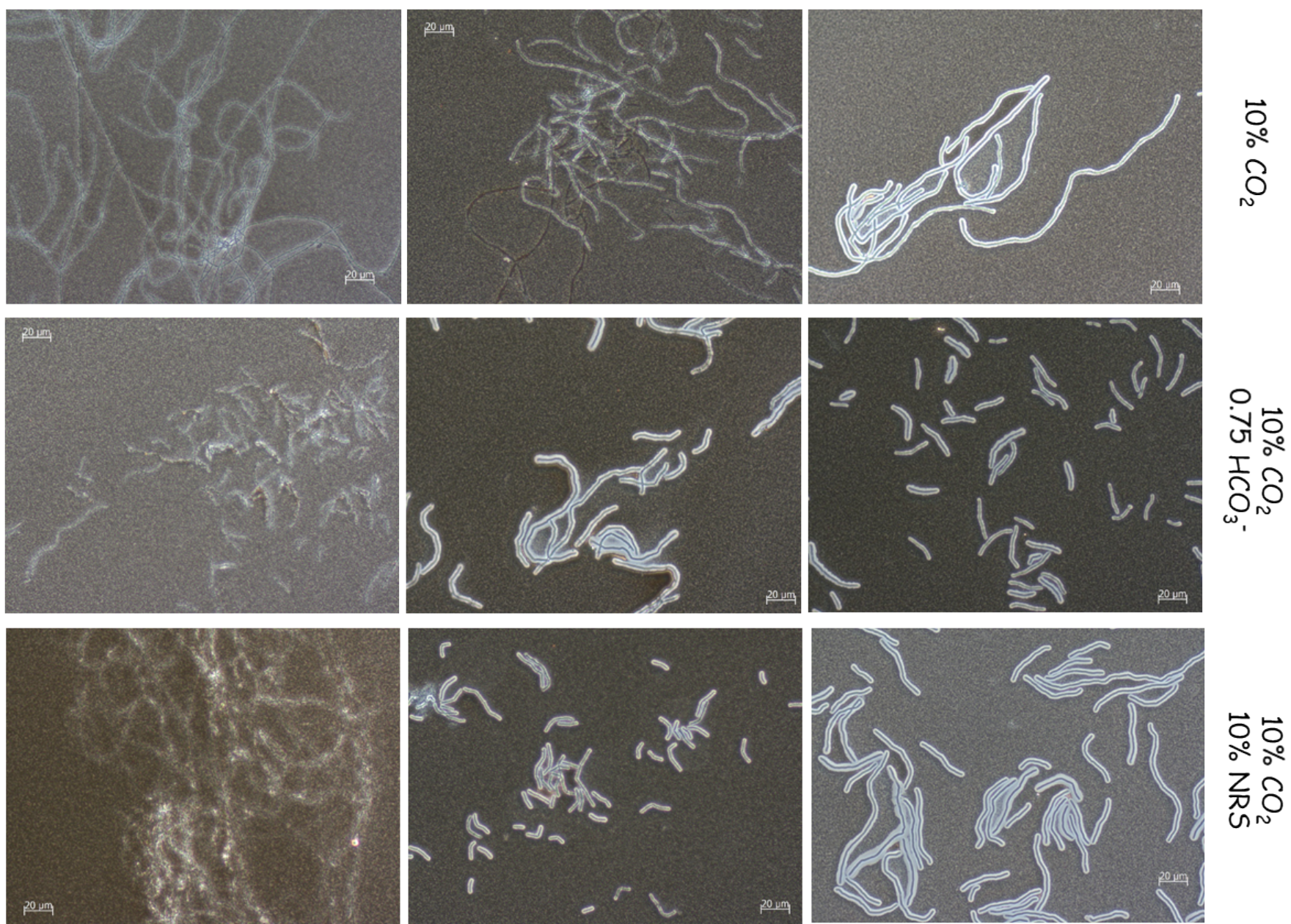

Figure 4. Capsule accumulation in response to $\mathrm{HCO}_{3}$ - in a $\mathrm{PA}_{\text {prom }}$ - regulated genome cluster of CAP operon.

Spores were seeded into $100 \mu \mathrm{l}$ of DMEM as is or supplemented with $0.75 \% \mathrm{HCO}_{3}^{-}$or $10 \% \mathrm{NRS}$ and incubated at $37^{\circ} \mathrm{C}$ in an atmosphere of $10 \% \mathrm{CO}_{2}$ for $24 \mathrm{~h}$. The presence or absence of capsule were determined by India ink negative staining (capsule seen as a bright outer layer). The different mutations are indicated (top panel).

While $10 \% \mathrm{CO}_{2}$ atmosphere induce capsule production in the Vollum wild type strain little or no capsule production could be detected in the Vollum $\triangle \mathrm{pXO2}$ chimeric strain (Figure 4). Supplementing the media with $0.75 \% \mathrm{HCO}_{3}{ }^{-}$to the growth medium results in capsule accumulation in the Vollum and Vollum $\triangle \mathrm{pXO2}$ chimera, however deletion if the at $X A$ resulted in capsule loss of the Vollum $\triangle \mathrm{p} X O 2$ chimeric strain (Figure 4). Same results were obtained by supplementing the medium with $10 \%$ NRS. These results support the PA secretion experiment that indicate that $\mathrm{HCO}_{3}$ and $\mathrm{NRS}$ are inducing toxin secretion in an atxA dependent manner. 
213 The effect of short incubation on capsule and toxins accumulation in response the different growth

214 conditions. Aerobic growth affects different parameters of the liquid medium such as $\mathrm{pH}$ and $\mathrm{O}_{2} / \mathrm{CO}_{2}$ 215 concentrations especially when the bacteria reaches high concentration (CFU/ml). As was shown 216 previously, capsule production and toxins secretion can be detected following 2-5h of growth in SDMEM 217 in $10 \% \mathrm{CO}_{2}$ atmosphere. To eliminate as much as possible the changes in media condition as result of 218 bacterial growth we examine capsule production and PA secretion following 5 h growth in different growth 219 conditions. Growth of the Vollum strain in ambient condition did not result in any capsule accumulation or 220 toxin secretion following $24 \mathrm{~h}$ incubation (Figure 2, Table 1) or a short $5 \mathrm{~h}$ incubation (Figure 5, Table 3). 221 Supplementing the media with 10\% NRS induced capsule production and PA secretion flowing $24 \mathrm{~h}$ 222 incubation in ambient atmosphere (Figure 2, Table 1). Examination these parameters following a shorter 2235 incubation, demonstrating PA accumulation (Table 3) but no capsule accumulation (Figure 5). This PA 224 accumulation is AtXA dependent as deletion of the at $X A$ gene resulted in no PA accumulation following $5 \mathrm{~h}$ 225 (Table 3) or $24 \mathrm{~h}$ incubation (Table 1). Incubating the bacteria in $10 \% \mathrm{CO}_{2}$ atmosphere for $5 \mathrm{~h}$ result in 226 capsule accumulation (Figure 5) the same as was observed following a 24 h incubation (Figures 1 -3). This 227 capsule accumulation was at $\times A$ independent and was not dramatically affected by the addition of $10 \%$ NRS 228 or $\mathrm{HCO}_{3}^{-}$(Figure 5). PA secretion was not induced by $10 \% \mathrm{CO}_{2}$ per se buy required addition of NRS or $\mathrm{HCO}_{3}^{-}$(Table 3), however unlike the $24 \mathrm{~h}$ incubation (Table 2), the PA that was secreted in respond to $230 \mathrm{HCO}_{3}$ - was less than $10 \%$ of that induced by NRS (Table 3 ). Under all conditions the PA secretion was AtXA dependent. 

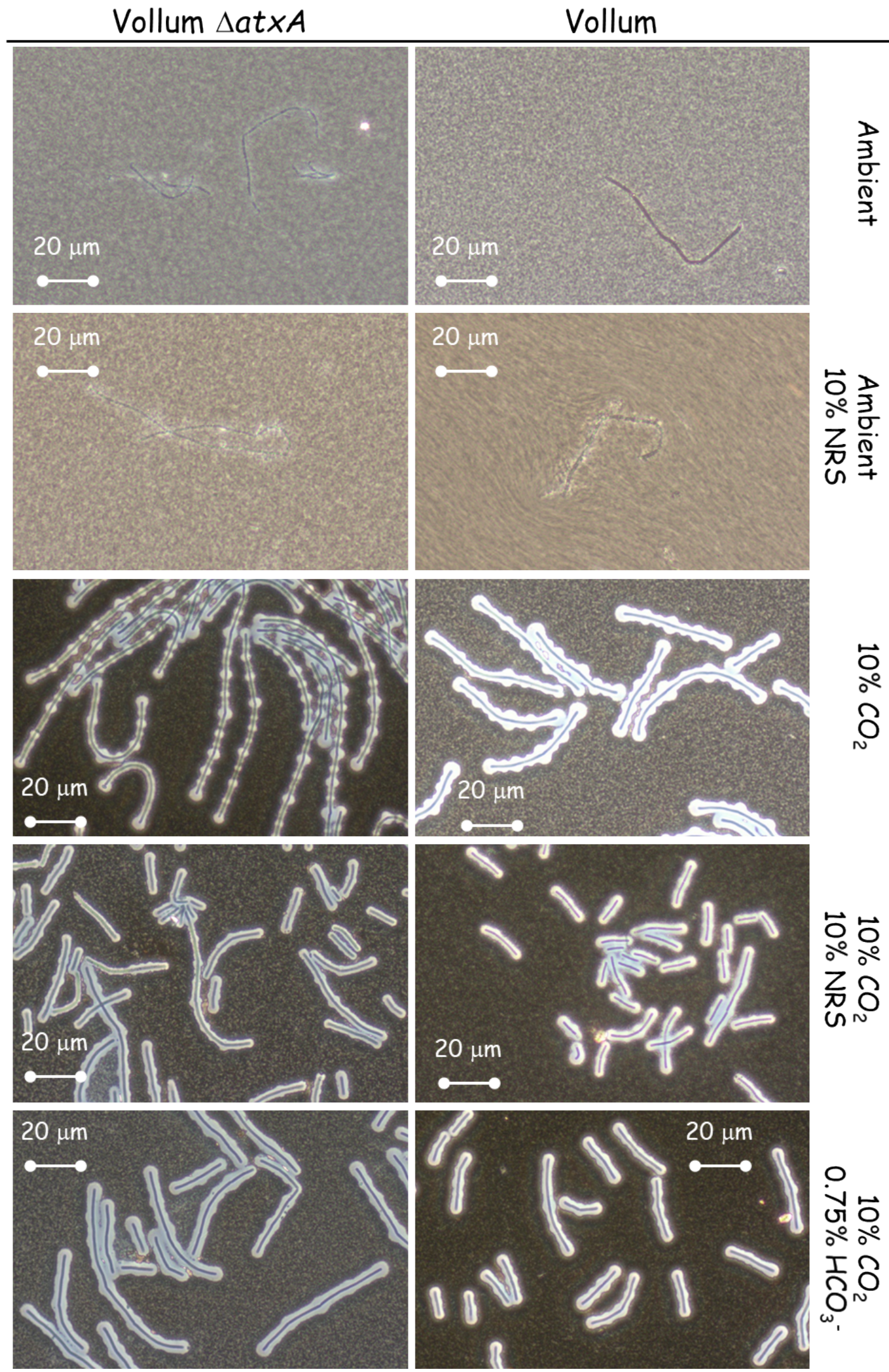

236 Figure 5. Effect of the absence of atxA gene on capsule accumulation after short (5h) growth under the 237 different growth conditions. Spores of the wild type and $\triangle a t \times A$ mutant (top panel) were seeded into $100 \mu l$ of DMEM as is or supplemented with $10 \%$ NRS and incubated at $37{ }^{\circ} \mathrm{C}$ in an ambient or $10 \% \mathrm{CO}_{2}$ atmosphere (as indicated 
on the right) for 24h. The presence or absence of capsule were determined by India ink negative staining (capsule

Table 3. PA secretion by Vollum and Vollum $\triangle$ at $x A$ flowing 5 h growth in different conditions

\begin{tabular}{|c|c|c|c|c|}
\hline & Vollum $\Delta a t \times A$ & Vollum & Atmosphere & Supplements \\
\hline \multirow{5}{*}{$\begin{array}{l}\bar{\xi} \\
\text { S } \\
\frac{\Xi}{\square} \\
\square\end{array}$} & $<0.1$ & $<0.1$ & Ambient & \\
\hline & $<0.1$ & 1.89 & Ambient & $10 \%$ NRS \\
\hline & $<0.1$ & $<0.1$ & $10 \% \mathrm{CO}_{2}$ & \\
\hline & & 4.25 & $10 \% \mathrm{CO}_{2}$ & $10 \%$ NRS \\
\hline & & 0.29 & $10 \% \mathrm{CO}_{2}$ & $0.75 \% \mathrm{HCO}_{3}-$ \\
\hline
\end{tabular}

Regulation of acpA and $a c p B$ in response to different growth conditions. As toxin production is induced in an atxA dependent manner in response to $\mathrm{HCO}_{3}$ - or NRS, capsule production is also induced by $\mathrm{CO}_{2}$ enriched (10\%) atmosphere. Since capsule production is regulated by two regulatory proteins, AcpA and $A C P B$, we tested the effect of the deletion of each on of these genes on capsule accumulation in response to the different growth conditions. The complete coding region of acp $A$ or acp $B$ was deleted independently in the wild type Vollum or the toxin deficient mutant Vollum $\Delta$ Tox (ref). As was previously shown for the wide type Vollum strain (Figure 2) none of these mutants accumulate capsule flowing growth in SDMEM with ambient atmosphere (Figure 6). The presence of acpA or acpB is sufficient for capsule accumulation in SDMEM supplemented with $10 \%$ NRS, regardless to the presence or absence of $10 \% \mathrm{CO}_{2}$ atmosphere (Figure 6). However, in the absence of NRS, only AcpA expressing mutants accumulate significant capsule when grown in $10 \% \mathrm{CO}_{2}$ atmosphere. $0.75 \% \mathrm{HCO}_{3}$ - induced capsule accumulation in the presence of acpA or acpB. Mutants deleted of acpA (expressing only acpB), did not accumulate significant capsule in $10 \% \mathrm{CO}_{2}$ atmosphere. To examine the role of at $x A$ in these processes, we deleted the at $x A$ gene in our Vollum $\triangle T 0 x \triangle a c p A$ or $\triangle a c p B$ mutants. Deleting the $\triangle a t \times A$ in the Vollum $\triangle T o x \triangle a c p A$, which express only the $a c p B$, abolishes capsule accumulation under all tested conditions (Figure 7). However, deleting the at $x A$ gene in the Vollum $\triangle T 0 x \triangle a c p B$, which express only acpA did not affect capsule accumulation, relative to the at $x A$ expressing mutant, indicating that acp $A$ operates in an atx $A$ independent manner (Figure 7).

As we demonstrated (Figure 2), capsule accumulation could be induced in ambient atmosphere by adding $10 \%$ NRS to the growth media. This induction is AtxA dependent since no capsule accumulation was detected in the Vollum $\triangle a t \times A$ mutant under these conditions (Figure 2). Since AcpA dependent capsule accumulation in $10 \% \mathrm{CO}_{2}$ atmosphere was $A+x A$ independent, we tested the role of AtxA on AcpA dependent capsule accumulation in response to $10 \%$ NRS in ambient atmosphere. As $10 \%$ NRS induces capsule accumulation of Vollum $\triangle a c p B$ in ambient atmosphere (Figure 6, Figure 8) we tested the effect 
bioRxiv preprint doi: https://doi.org/10.1101/2022.02.21.481328; this version posted February 21, 2022. The copyright holder for this preprint (which was not certified by peer review) is the author/funder, who has granted bioRxiv a license to display the preprint in perpetuity. It is made available under aCC-BY 4.0 International license.

268 of atxA deletion on capsule accumulation under these conditions. Unlike the $\mathrm{CO}_{2}$ induction, in ambient

269 atmosphere, AcpA dependent capsule accumulation in response to NRS is AtxA dependent (Figure 8).

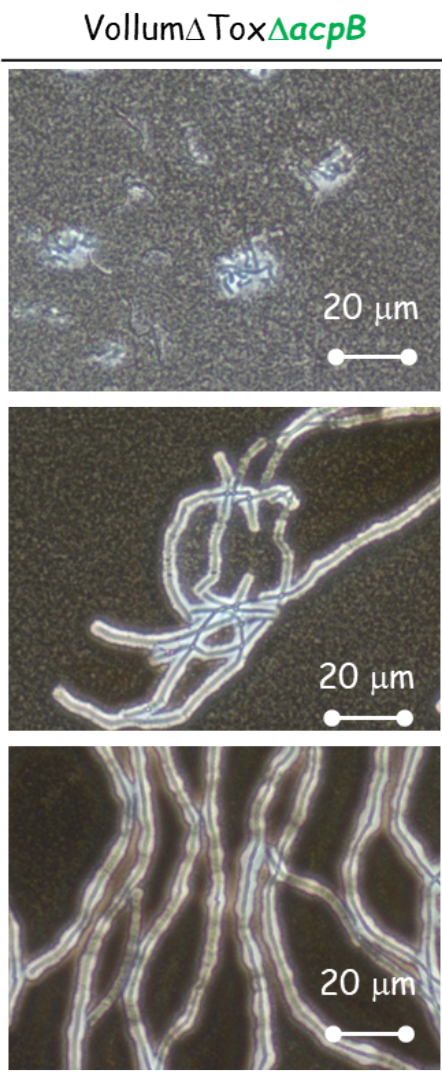
Vollum $\triangle a c p B$

Vollum $\Delta$ Tox $\Delta a c p A$

Vollum $\triangle a c p A$
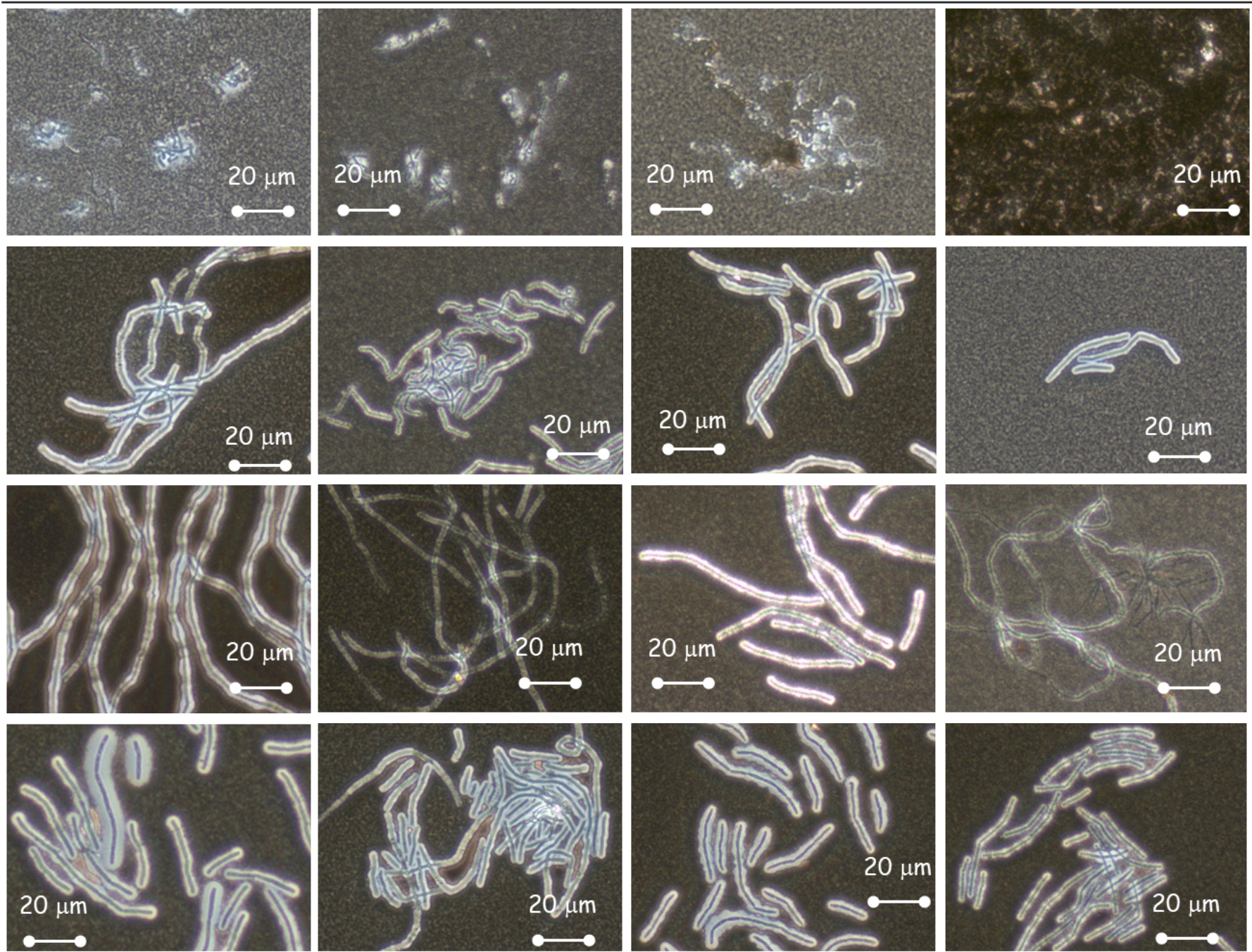

$\frac{3}{3}$
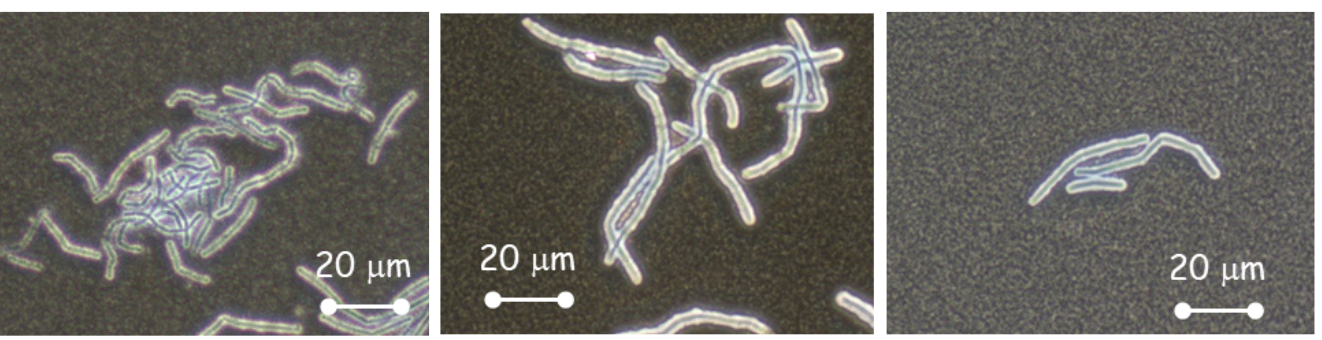

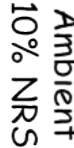
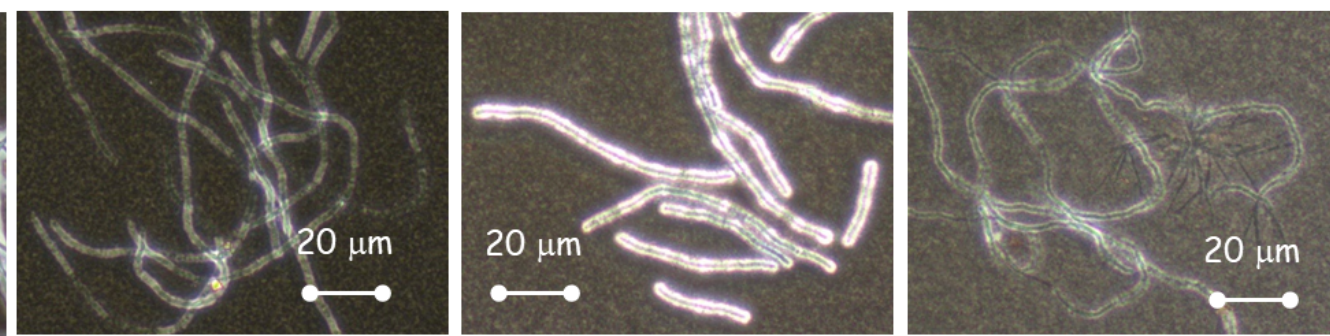

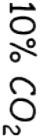
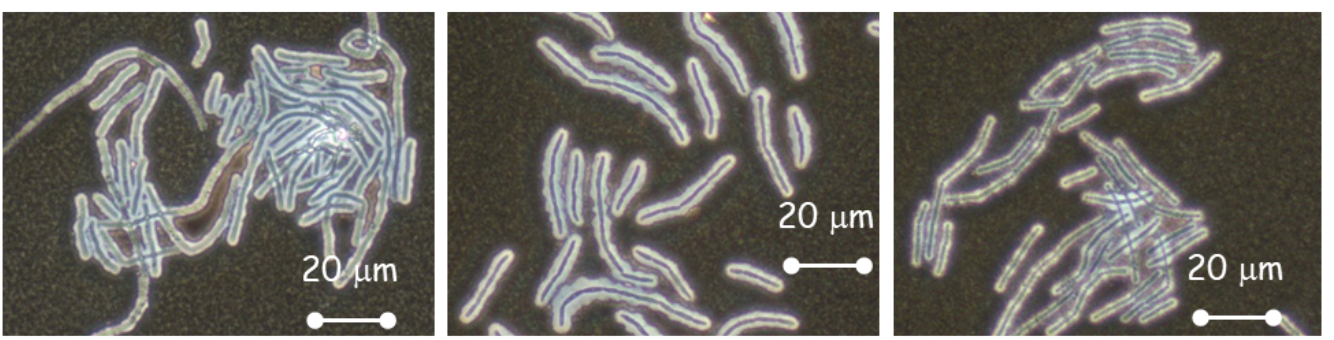

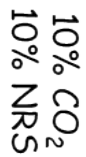
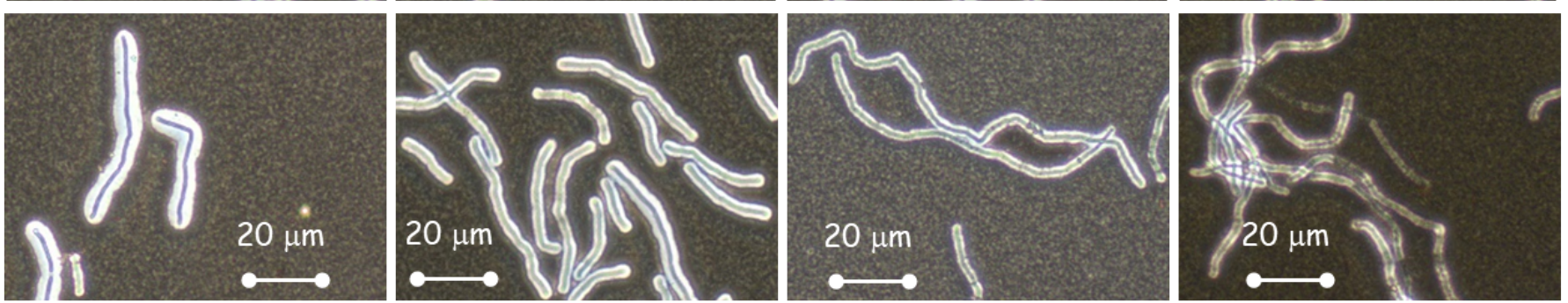

0

जै

ภㅇำ

ก ก

$\omega$,

270

271 Figure 6. The effect of absence of acpA or acpB on capsule accumulation in response to $10 \%$ NRS in an

272 ambient or $10 \% \mathrm{CO}_{2}$ atmosphere. Spores of the $\triangle a c p A$ or acpB mutants (top panel) were seeded into $100 \mu \mathrm{l}$ of

273 DMEM as is or supplemented with $0.75 \% \mathrm{HCO}_{3}{ }^{-}$or $10 \% \mathrm{NRS}$ and incubated at $37^{\circ} \mathrm{C}$ in an ambient or $10 \% \mathrm{CO}_{2}$

274 atmosphere (as indicated on the right) for 24h. The presence or absence of capsule were determined by India ink

275 negative staining (capsule seen as a bright outer layer). 
bioRxiv preprint doi: https://doi.org/10.1101/2022.02.21.481328; this version posted February 21, 2022. The copyright holder for this preprint (which was not certified by peer review) is the author/funder, who has granted bioRxiv a license to display the preprint in perpetuity. It is made available under aCC-BY 4.0 International license.

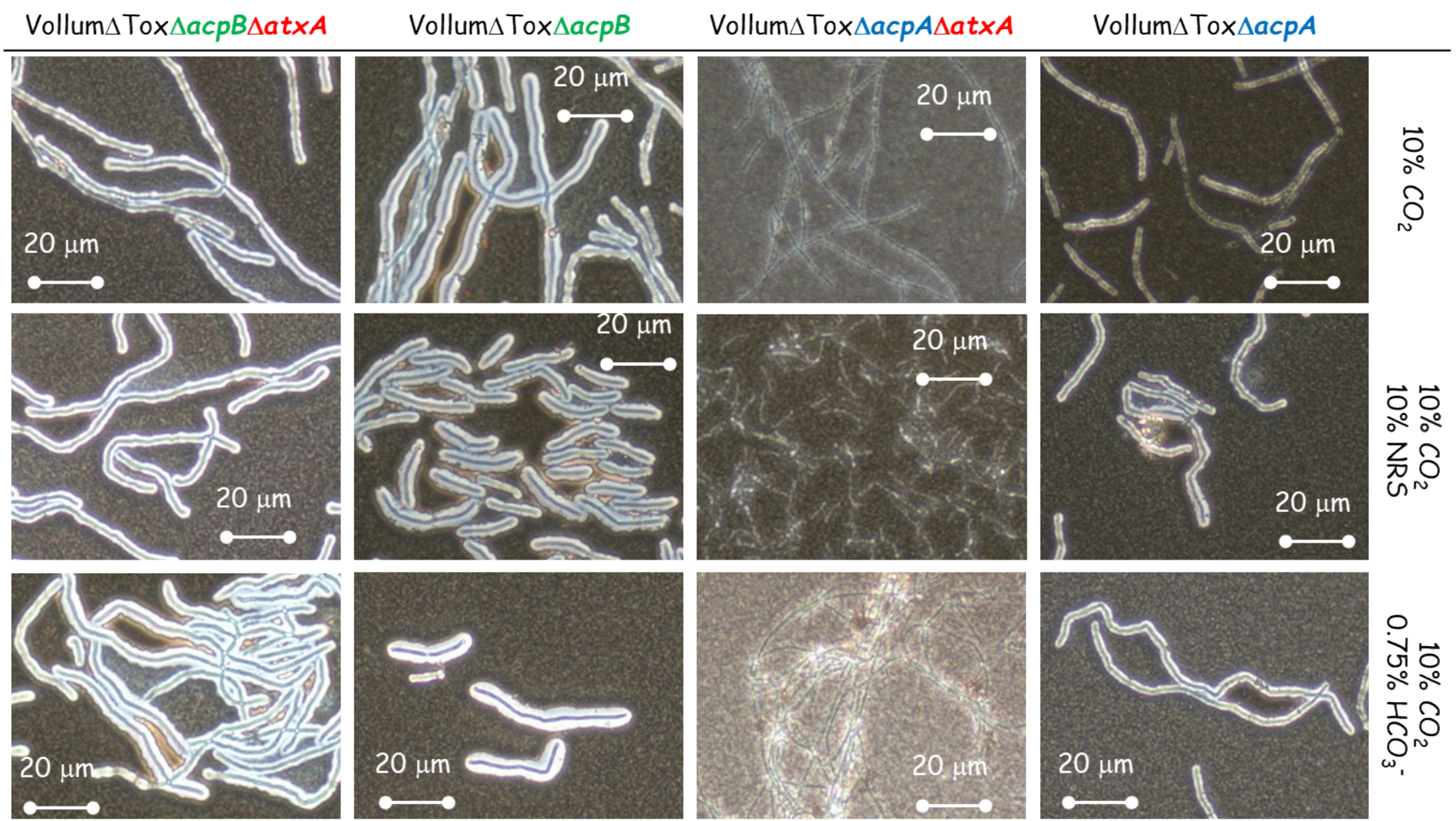

277 Figure 7. Effect of AtxA on Capsule accumulation in the presence of only AcpA or AcpB. Spores of the

278 different mutants (top panel) were seeded into $100 \mu$ l of DMEM as is or supplemented with $0.75 \% \mathrm{HCO}_{3}^{-}$or $10 \% \mathrm{NRS}^{-1}$

279 and incubated at $37{ }^{\circ} \mathrm{C}$ in $10 \% \mathrm{CO}_{2}$ atmosphere (as indicated on the right) for $24 \mathrm{~h}$. The presence or absence of capsule 280 were determined by India ink negative staining (capsule seen as a bright outer layer).

281

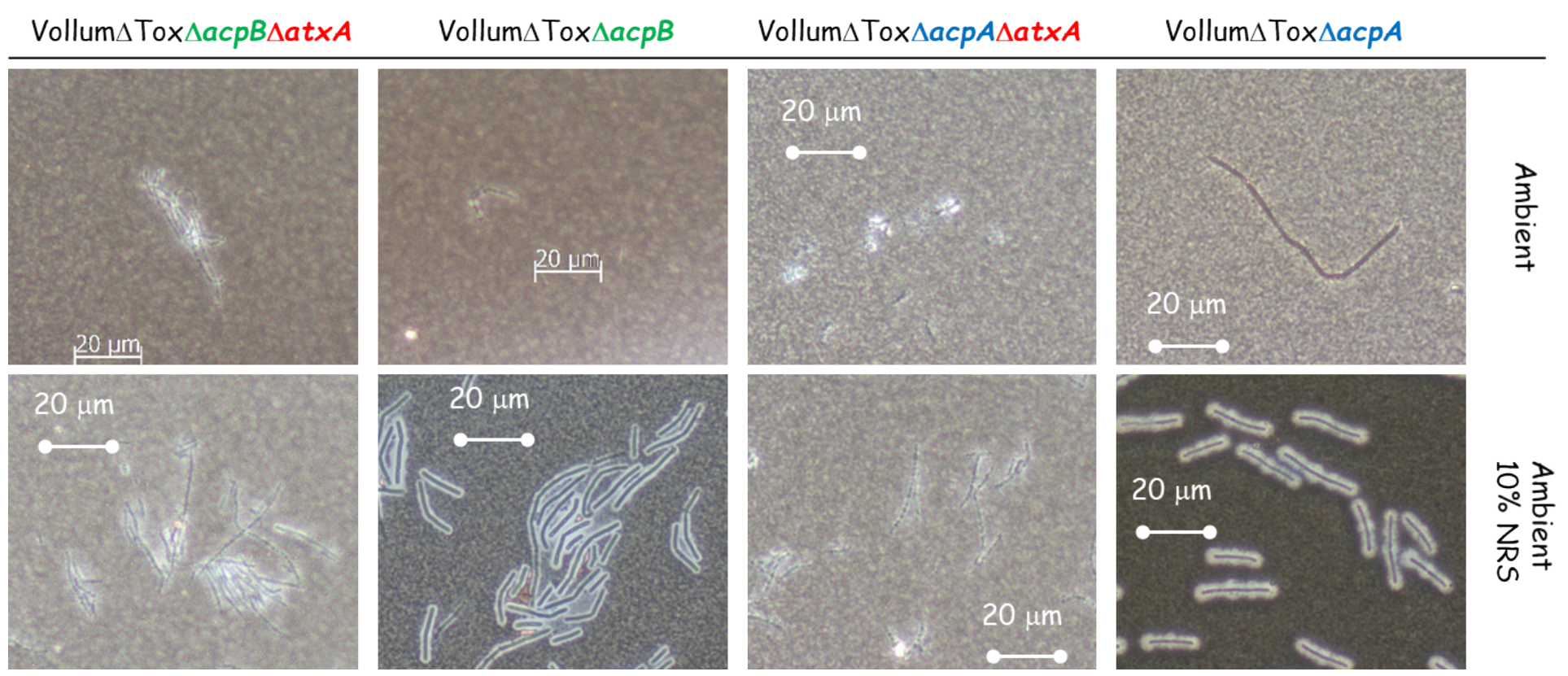

282 Figure 8. Effect of AtxA on Capsule accumulation in response to $10 \%$ NRS in ambient atmosphere. Spores

283 of the different mutants (top panel) were seeded into $100 \mu$ l of DMEM as is or supplemented with $10 \%$ NRS and 
bioRxiv preprint doi: https://doi.org/10.1101/2022.02.21.481328; this version posted February 21, 2022. The copyright holder for this preprint (which was not certified by peer review) is the author/funder, who has granted bioRxiv a license to display the preprint in perpetuity. It is made available under aCC-BY 4.0 International license.

284 incubated at $37^{\circ} \mathrm{C}$ in ambient atmosphere (as indicated on the right) for $24 \mathrm{~h}$. The presence or absence of capsule 285 were determined by India ink negative staining (capsule seen as a bright outer layer). 
290 For successful invasion the pathogen mast regulates its virulence factors in a way that will maximize their 291 effect on the host defense mechanisms. The trigger of such activation is usually host derived and can be biological (such as proteins) of physical ( $\mathrm{pH}$ or temperature for example). B. anthracis naturally infect humans following spore inhalation, contact with broken skin or ingestion of undercook contaminated meat, in each of them the bacteria faces different environmental conditions [2]. It was previously demonstrated that toxins secretion and capsule accumulation could be induced by growing the bacteria in culture media supplemented with $\mathrm{HCO}_{3}{ }^{-}$or serum (10-50\%) in a $\mathrm{CO}_{2}$ enriched (5-15\%) atmosphere $[5,16,18,19,26-28]$. $\mathrm{HCO}_{3}-1 \mathrm{CO}_{2}$ condition were used to study in most studies of atxA, acpA and acp $B$ regulation and their effect on toxins and capsule biosynthetic genes $[16,18,29]$. Since these conditions always included these two components it was concluded that at $x A$ was induced in response to $\mathrm{CO}_{2}$ and regulate the induction of acp $A$ and $a c p B$. Although in some reports, capsule accumulation was shown to be atxA dependent $[16,30]$, the fact that $\triangle \mathrm{pXO1}$ variants are encapsulated contradict this finding, indicating addition at $X$ independent regulation of the process $[19,26]$. The use of SDMEM as a growth media enabled the examination of the effect of $\mathrm{CO}_{2}, \mathrm{HCO}_{3}^{-}$and serum on these processes.

304 The parameter of soluble $\mathrm{CO}_{2}$ is influenced by multiple parameters such as surface area to volume ratio and aerobic bacterial growth. Therefore, normal growth conditions were determined as $100 \mu \mathrm{lmedia} /$ well of a 96 well tissue culture plate for $24 \mathrm{~h}$ at $37^{\circ} \mathrm{C}$ in ambient condition (Figure 1). This baseline enabled testing of the different supplements and/or growth conditions on capsule (Figure 1) or toxin (Figure 2 , Table 1). Capsule production is induced by the addition of $10 \%$ NRS or growth in a $10 \% \mathrm{CO}_{2}$ atmosphere (Figure 1). The serum capsule induction (in ambient atmosphere) is at $X A$ dependent (Figure 2) since there was no significant capsule accumulation it the mutants that did not express AtxA (Vollum $\triangle a t \times A$ and

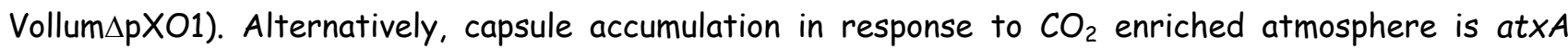
independent, as there is no significant difference in capsule accumulation under these conditions between AtXA expressing and at $X A$ null mutants (Figures 2, 3). Toxins secretion, as determined by PA media concentration is serum dependent (Tables 1,2), as PA could be detected only in NRS supplemented SDMEM regardless of the $\mathrm{CO}_{2}$ enriched atmosphere. $\mathrm{HCO}_{3}$ - as serum induced toxin secretion in an atxA dependent manner (Figure 3, Table 2) were PA accumulated in the wild type Vollum and not in the atx $A$ null mutant. The same $\mathrm{NRS} / \mathrm{HCO}_{2}$ - dependence and $\mathrm{CO}_{2}$ independence of pag (PA) induction was demonstrated using a priestly reported mutant stain which is missing pXO2 and have a chromosomal copy of the CAP operon regulated by a pag promotor [17]. This mutant strain accumulates capsule when grown in SDMEM that was supplemented with NRS or $\mathrm{HCO}_{3}^{-}$but not in SDMEM in $10 \% \mathrm{CO}_{2}$ atmosphere. 
We found differences in rates that B. anthracis reacts to the different stimulants. Examining the toxins recreation and capsule accumulation after short incubation of $5 \mathrm{~h} . \mathrm{HCO}_{3}^{-}$was not as robust as NRS in inducing toxins secretion. Examining the PA concertation after $5 \mathrm{~h}$ incubation in DMEM supplemented with $0.75 \% \mathrm{HCO}_{3}-$ revealed about $1 / 10$ of the concentration after a $24 \mathrm{~h}$ incubation (Figure 5, Table 3 ), were with NRS the concentration in these two timepoints was similar. Testing the effect of serum on capsule accumulation reviles that $5 \mathrm{~h}$ incubation in ambient atmosphere which result in significant PA secretion, did not result in significant capsule accumulation. 5h growth in a $10 \% \mathrm{CO}_{2}$ atmosphere induced capsule

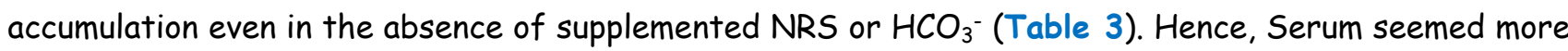
effective then $\mathrm{HCO}_{3}^{-}$in inducing toxin secretion, two process that are atxA dependent. The atxA independent $10 \% \mathrm{CO}_{2}$ atmosphere appeared more effective then atxA dependent serum for capsule accumulation (Figure 5).

Two major regulators; $A C P A$ and $A C P B$ controle capsule biosynthetic by promoting transcription of acp $B, C, A, D, E$ operon. acpA was shown to be regulated by at $x A$ (assumed by $\mathrm{CO}_{2}$ and $\mathrm{HCO}_{3}^{-}$) and to possess an additional at $X A$ independent promotor. We found that by deleting acp $A$ the mutant accumulates significantly less capsule in response to $\mathrm{CO}_{2}$ but maintain its ability to respond to $\mathrm{NRS}$ or $\mathrm{HCO}_{3}$ - (Figure 6). Deletion of $a c p B$ did not have any effect on capsule accumulation under all tested conditions (Figure 6) which support our previous in vivo data. Deletion of both atx $A$ and acpA or acpB revealed that $A c p B$ activity is strictly AtXA dependent under all the conditions tested (Figure7). AcpA activity is not affected by the absence of at $X A$ in the presence of $\mathrm{CO}_{2}$ (Figure7) but is nulled in response to NRS in an ambient environment (Figure 8).

Our findings support the following regulation cascade; $\mathrm{CO}_{2}$ is inducing capsule accumulation via the activation of acpA in an $A+x A$ independent manner. Serum activate the AtxA dependent cascade that induce toxins secretion and eventually capsule accumulation by activating acp $A$ and acpB (Figure 9) since there was no capsule accumulation following $5 \mathrm{~h}$ growth in NRS containing in ambient atmosphere (Figure 5). $\mathrm{HCO}_{3}{ }^{-}$induces toxin secretion by AtXA cascade, in a less efficient manner (relative to NRS, Table 3 ). Direct activation of capsule accumulation by $\mathrm{HCO}_{3}{ }^{-}$in $\mathrm{AtXA}$ independent manner could not be eliminate since even in ambient atmosphere, it modifies the levels of soluble $\mathrm{CO}_{2}\left(\mathrm{PCO}_{2}\right)$ and possibly induces capsule production via acpA. Theoretically, this differential regulation of toxins and capsule have logical role in B. anthracis pathogenicity. Inhalational and cutaneous infection involve spore engulfing and migration to a draining lymph node. Within the phagocytic (dendritic) cell the spore germinates and produce capsule that protect the bacteria form pagolysis. Toxin production in this stage in counterproductive as it could result in cell arrest that might interfere with the pathogenic pathway. Toxin production may enhance 
bioRxiv preprint doi: https://doi org/10.1101/2022 02.21 .481328 ; this version posted February 21,2022 . The copyright holder for this preprint (which was not certified by peer review) is the author/funder, who has granted bioRxiv a license to display the preprint in perpetuity. It is made available under aCC-BY 4.0 International license.

once the bacteria is released from the cell in the lymph node. The serum and $\mathrm{CO}_{2}$ sensing pathway is still

to be determined and might be common to other pathogens and therefore be a target for therapeutics.

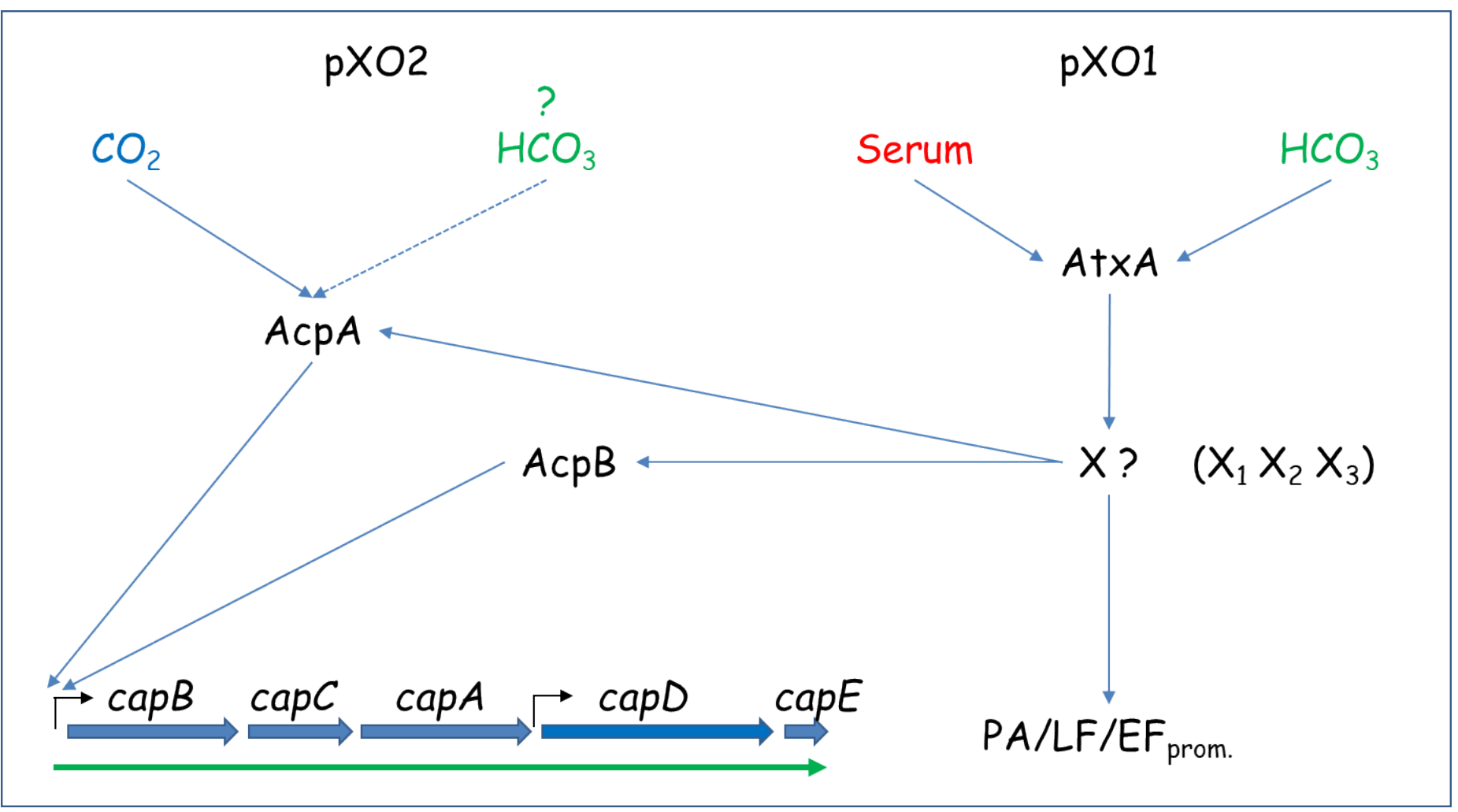

355 Figure 9. Proposed regulation of $\mathrm{CO}_{2}$, Serum and $\mathrm{HCO}_{3}^{-}$on capsule production and toxin secretion. 
360 1. Dixon TC, Meselson M, Guillemin J, Hanna PC. Anthrax. New England Journal of Medicine. 361 1999:341(11):815-26. doi: 10.1056/nejm199909093411107. PubMed PMID: 10477781.

362 2. Hanna P. Anthrax pathogenesis and host response. Curr Top Microbiol Immunol. 1998;225:13-35. 363 Epub 1997/12/05. PubMed PMID: 9386326.

3643 3. Swartz MN. Recognition and management of anthrax--an update. $N$ Engl J Med. 2001;345(22):1621-6. Epub 2001/11/13. doi: 10.1056/NEJMra012892. PubMed PMID: 11704686.

4. Candela $T$, Fouet $A$. Bacillus anthracis CapD, belonging to the gamma-glutamyltranspeptidase family, is required for the covalent anchoring of capsule to peptidoglycan. Mol Microbiol. 2005:57(3):71726. Epub 2005/07/28. doi: 10.1111/j.1365-2958.2005.04718.x. PubMed PMID: 16045616.

5. Candela T, Mock M, Fouet A. CapE, a 47-amino-acid peptide, is necessary for Bacillus anthracis polyglutamate capsule synthesis. J Bacteriol. 2005;187(22):7765-72. Epub 2005/11/04. doi: 10.1128/JB.187.22.7765-7772.2005. PubMed PMID: 16267300; PubMed Central PMCID: PMCPMC1280324.

6. Heine HS, Shadomy SV, Boyer AE, Chuvala L, Riggins R, Kesterson A, et al. Evaluation of Combination Drug Therapy for Treatment of Antibiotic-Resistant Inhalation Anthrax in a Murine Model. Antimicrob Agents Chemother. 2017:61(9). Epub 2017/07/12. doi: 10.1128/AAC.00788-17. PubMed PMID: 28696235; PubMed Central PMCID: PMCPMC5571330.

7. Candela T, Fouet A. Poly-gamma-glutamate in bacteria. Molecular Microbiology. 2006;60(5):10918. doi: doi:10.1111/j.1365-2958.2006.05179.x.

8. Wu R, Richter S, Zhang RG, Anderson VJ, Missiakas D, Joachimiak A. Crystal structure of Bacillus anthracis transpeptidase enzyme CapD. J Biol Chem. 2009;284(36):24406-14. Epub 2009/06/19. doi: 10.1074/jbc.M109.019034. PubMed PMID: 19535342; PubMed Central PMCID: PMCPMC2782033.

9. Richter S, Anderson VJ, Garufi G, Lu L, Budzik JM, Joachimiak A, et al. Capsule anchoring in Bacillus anthracis occurs by a transpeptidation reaction that is inhibited by capsidin. Mol Microbiol. 2009:71(2):404-20. Epub 2008/11/20. doi: 10.1111/j.1365-2958.2008.06533.x. PubMed PMID: 19017271; PubMed Central PMCID: PMCPMC2770442.

10. Klimpel KR, Arora N, Leppla SH. Anthrax toxin lethal factor contains a zinc metalloprotease consensus sequence which is required for lethal toxin activity. Mol Microbiol. 1994;13(6):1093-100. Epub 1994/09/01. doi: 10.1111/j.1365-2958.1994.tb00500.x. PubMed PMID: 7854123.

11. Tang W-J, Guo Q. The adenylyl cyclase activity of anthrax edema factor. Molecular Aspects of Medicine. 2009:30(6):423-30.

12. Liu S, Moayeri M, Leppla SH. Anthrax lethal and edema toxins in anthrax pathogenesis. Trends Microbiol. 2014:22(6):317-25. Epub 2014/04/02. doi: 10.1016/j.tim.2014.02.012. PubMed PMID: 24684968; PubMed Central PMCID: PMCPMC4041834.

13. Ebrahimi CM, Kern JW, Sheen TR, Ebrahimi-Fardooee MA, van Sorge NM, Schneewind O, et al. Penetration of the blood-brain barrier by Bacillus anthracis requires the pXO1-encoded BsIA protein. $J$ Bacteriol. 2009:191(23):7165-73. Epub 2009/10/13. doi: 10.1128/JB.00903-09. PubMed PMID: 19820089: PubMed Central PMCID: PMCPMC2786561.

14. Uchida I, Hornung JM, Thorne CB, Klimpel KR, Leppla SH. Cloning and characterization of a gene whose product is a trans-activator of anthrax toxin synthesis. J Bacteriol. 1993;175(17):5329-38. Epub 1993/09/01. doi: 10.1128/jb.175.17.5329-5338.1993. PubMed PMID: 8366021; PubMed Central PMCID: PMCPMC206586.

15. Dai Z, Sirard JC, Mock M, Koehler TM. The atXA gene product activates transcription of the anthrax toxin genes and is essential for virulence. Mol Microbiol. 1995;16(6):1171-81. Epub 1995/06/01. doi: 10.1111/j.1365-2958.1995.tb02340.x. PubMed PMID: 8577251.

16. Drysdale M, Bourgogne A, Hilsenbeck $S G$, Koehler TM. at $x A$ controls Bacillus anthracis capsule synthesis via acpA and a newly discovered regulator, acpB. J Bacteriol. 2004:186(2):307-15. Epub 
2004/01/02. doi: 10.1128/jb.186.2.307-315.2004. PubMed PMID: 14702298; PubMed Central PMCID: PMCPMC305762.

17. Sittner A, Bar-David E, Glinert I, Ben-Shmuel A, Schlomovitz J, Levy H, et al. Role of acpA and $a c p B$ in Bacillus anthracis capsule accumulation and toxin independent pathogenicity in rabbits. Microb Pathog. 2021:155:104904. Epub 2021/05/01. doi: 10.1016/j.micpath.2021.104904. PubMed PMID: 33930422.

18. Fouet A. AtxA, a Bacillus anthracis global virulence regulator. Res Microbiol. 2010;161(9):735-42. Epub 2010/09/25. doi: 10.1016/j.resmic.2010.09.006. PubMed PMID: 20863885.

19. Levy H, Glinert I, Weiss S, Sittner A, Schlomovitz J, Altboum Z, et al. Toxin-independent virulence of Bacillus anthracis in rabbits. PLoS One. 2014:9(1):e84947. Epub 2014/01/15. doi: 10.1371/journal.pone.0084947. PubMed PMID: 24416317; PubMed Central PMCID: PMCPMC3885664.

20. Fouet $A$, Mock M. Differential influence of the two Bacillus anthracis plasmids on regulation of virulence gene expression. Infect Immun. 1996:64(12):4928-32. Epub 1996/12/01. doi: 10.1128/IAI.64.12.4928-4932.1996. PubMed PMID: 8945528; PubMed Central PMCID: PMCPMC174470. 21. Bertin M, Chateau $A$, Fouet $A$. Full expression of Bacillus anthracis toxin gene in the presence of bicarbonate requires a 2.7-kb-long at $x A$ mRNA that contains a terminator structure. Res Microbiol. 2010;161(4):249-59. Epub 2010/04/03. doi: 10.1016/j.resmic.2010.03.003. PubMed PMID: 20359529.

22. Vietri NJ, Marrero R, Hoover TA, Welkos SL. Identification and characterization of a transactivator involved in the regulation of encapsulation by Bacillus anthracis. Gene. 1995;152(1):1-9. Epub 1995/01/11. doi: 10.1016/0378-1119(94)00662-c. PubMed PMID: 7828912.

23. Levy H, Weiss S, Altboum Z, Schlomovitz J, Glinert I, Sittner A, et al. Differential Contribution of Bacillus anthracis Toxins to Pathogenicity in Two Animal Models. Infect Immun. 2012;80(8):2623-31. Epub 2012/05/16. doi: IAI.00244-12 [pii] 10.1128/IAI.00244-12. PubMed PMID: 22585968.

24. Levy $H$, Fisher $M$, Ariel $N$, Altboum $Z$, Kobiler D. Identification of strain specific markers in Bacillus anthracis by random amplification of polymorphic DNA. FEMS Microbiol Lett. 2005;244(1):199205. PubMed PMID: 15727841.

25. Levy H, Weiss S, Altboum Z, Schlomovitz J, Rothschild N, Glinert I, et al. The effect of deletion of the edema factor on Bacillus anthracis pathogenicity in guinea pigs and rabbits. Microb Pathog. 2012;52(1):55-60. Epub 2011/10/25. doi: S0882-4010(11)00184-7 [pii]

10.1016/j.micpath.2011.10.002. PubMed PMID: 22020310.

26. Welkos SL. Plasmid-associated virulence factors of non-toxigenic (pX01-) Bacillus anthracis. Microb Pathog. 1991;10(3):183-98. Epub 1991/03/01. doi: 10.1016/0882-4010(91)90053-d. PubMed PMID: 1654495.

27. Chiang $C$, Bongiorni $C$, Perego M. Glucose-dependent activation of Bacillus anthracis toxin gene expression and virulence requires the carbon catabolite protein CcpA. J Bacteriol. 2011;193(1):52-62. Epub 2010/10/26. doi: 10.1128/JB.01656-09. PubMed PMID: 20971911; PubMed Central PMCID: PMCPMC3019961.

28. McCall RM, Sievers ME, Fattah R, Ghirlando R, Pomerantsev AP, Leppla SH. Bacillus anthracis Virulence Regulator AtxA Binds Specifically to the pagA Promoter Region. J Bacteriol. 2019;201(23). Epub 2019/10/02. doi: 10.1128/JB.00569-19. PubMed PMID: 31570528; PubMed Central PMCID: PMCPMC6832065.

29. Guignot J, Mock M, Fouet A. AtxA activates the transcription of genes harbored by both Bacillus anthracis virulence plasmids. FEMS Microbiol Lett. 1997:147(2):203-7. Epub 1997/02/15. doi: 10.1111/j.1574-6968.1997.tb10242.x. PubMed PMID: 9119194.

30. Drysdale M, Bourgogne A, Koehler TM. Transcriptional analysis of the Bacillus anthracis capsule regulators. J Bacteriol. 2005;187(15):5108-14. Epub 2005/07/21. doi: 10.1128/JB.187.15.51085114.2005. PubMed PMID: 16030203; PubMed Central PMCID: PMCPMC1196023. 